\title{
Assessing natural capital value in the network of Italian marine protected areas: a comparative approach
}

\author{
Elvira Buonocore ${ }^{1,2}$, Giovanni F. Russo ${ }^{1,2}$, Pier Paolo Franzese ${ }^{1,2 *}$ \\ ${ }^{1}$ UNESCO Chair in "Environment, Resources and Sustainable Development", Department of Science \\ and Technology, Parthenope University of Naples, Villa Doria d'Angri n.80 (80123) Naples, Italy \\ ${ }^{2}$ CoNISMa, Piazzale Flaminio 9, 00197 Rome, Italy \\ *Corresponding author e-mail: pierpaolo.franzese@uniparthenope.it
}

Received: 27 June 2020 / Accepted: 29 July 2020

\begin{abstract}
Marine and coastal natural capital stocks provide a bundle of ecosystem services vital for human well-being. The biophysical and economic assessment of the value of natural capital stocks is much needed for achieving nature conservation goals, while ensuring the sustainable exploitation of marine resources. Marine Protected Areas (MPAs) are increasingly being established worldwide to protect and conserve natural capital stocks from anthropogenic threats. In this study, a biophysical and trophodynamic model based on the emergy accounting method was used to assess the value of natural capital for a set of Italian MPAs. In particular, the assessment focused on four main macro-habitats: 1) sciaphilic hard bottom (SHB), 2) photophilic hard bottom (PHB), 3) soft bottom (SB), and 4) Posidonia oceanica seagrass beds (PSB). The emergy method allowed the assessment of natural capital stocks in terms of direct and indirect solar energy flows invested by nature for their generation. The SHB habitat showed the highest emergy density value in most of the investigated MPAs, confirming the high convergence of input resource flows in the formation of this habitat. When considering extensive indicators, the contribution of the PSB habitat to the total value of natural capital was higher than other habitats in most MPAs. In addition, to facilitate the understanding of the results in socio-economic contexts, the biophysical values of natural capital stocks were converted into monetary units. The total value of natural capital in the investigated MPAs ranged from about 8 to $1163 \mathrm{M} €$. In conclusion, assessing the value of natural capital can support local managers and policy makers in charge for achieving nature conservation targets while ensuring the sustainable exploitation of natural resources.
\end{abstract}

Keywords: environmental accounting; natural capital; marine ecosystems; marine protected areas.

\section{Introduction}

In the last decades, there has been growing awareness on the vital support natural ecosystems provide to human well-being both in scientific and policy contexts (Buonocore et al., 2018; Chan et al., 2016; Häyhä and Franzese, 2014; Pauna et al., 2018). The concepts of "natural capital" and "ecosystem services" are conceived to explore the interactions between natural ecosystems and human wellbeing. They are also meant to allow for a better understanding of when, where and to what extent humans may benefit from ecosystems, influence ecosystems and loose ecosystem functions and services with overexploitation of natural resources (van Dijk et al., 2018).

Marine and coastal ecosystems are recognized as among the most productive ecosystems in the world (UNEP, 2006; Hattam et al., 2015). Healthy, resilient, and diverse marine ecosystems are capable of generating and maintaining natural capital stocks while providing a bundle of ecosystem services vital for human economic development and wellbeing (Armoškaitė et al., 2020; Cattaneo-Vietti et al., 2016; Cavanagh et al., 2016; Vihervaara et al., 2019). 
Marine ecosystems are exposed to several anthropogenic pressures among which, pollution, overfishing, the introduction of invasive species, and acidification (Halpern et al., 2008; Pauna et al., 2019). The cumulative impact of human activities on marine ecosystems often leads to ecosystem degradation and biodiversity loss, also affecting their capacity to provide benefits to humans (Halpern et al., 2019).

Marine Protected Areas (MPAs) are important tools to protect and conserve natural capital stocks from different anthropogenic threats on marine ecosystems (Maestro et al., 2019; Rasheed et al., 2020). MPAs are characterized by interlinked social, economic, and ecological dynamics and represent complex conservation and management tools for achieving sustainability goals. Several studies show that MPAs contribute to biodiversity protection while ensuring the sustainable exploitation of marine resources (Halpern, 2003; OECD, 2017).

When effective management measures are in place, MPAs are able to meet the multitude of objectives they are designed for. Although an increasing number of MPAs has been established worldwide, efforts are still required for the evaluation and understanding of their effectiveness (UNEP-WCMC and IUCN, 2019). Therefore, novel multicriteria frameworks are much needed for assessing MPAs effectiveness and management performance, providing useful information to local managers and policy makers in charge of achieving local and large-scale sustainability goals (Rasheed, 2020).

Accounting for natural capital and ecosystem services value is the basis for the effective management of natural resources (Barbier, 2014; Yu et al., 2019). Over the past decade, there have been increasing research efforts to assess natural capital value and related ecosystem services in marine ecosystems, also exploring how these values can be embedded into decision making (Christie et al., 2015; Franzese et al., 2008, 2015; Schumann and Mahon, 2015; TEEB, 2010).

Recent studies provided an assessment of the biophysical value of natural capital in MPAs. In particular, Vassallo et al. (2017) developed a biophysical and trophodynamic model based on emergy accounting to assess the value of natural capital in MPAs. Franzese et al. (2017), Picone et al. (2017), Paoli et al. (2018), and Buonocore et al. $(2019,2020)$ assessed the biophysical value of natural capital in selected Mediterranean MPAs. Berrios et al. (2017) used emergy accounting to provide an evaluation of natural capital and ecosystem services of benthic marine ecosystems in Chile, also exploring their contributions to the well-being of regional economy.

In 2014, following the EU Biodiversity Strategy to 2020 guidelines, the Italian Ministry of the Environment and Protection of Land and Sea financed a 4-years research programme entitled "Environmental Account- ing in Italian Marine Protected Areas" and based on the implementation of an environmental accounting system for all the twenty-nine Italian MPAs. The purpose of the project was to carry out a biophysical and economic assessment of natural capital stocks and ecosystem services flows (Franzese et al., 2015). The project also aimed at the spatial representation of both the ecological and economic value of natural capital to support marine spatial planning and the sustainable management of biological resources.

In this study, we present a synthesis of the results of this national project dealing with natural capital assessment for selected Italian MPAs.

\section{Materials and methods}

\subsection{The network of Italian marine protected areas}

The network of Italian MPAs includes 29 sites protecting about 228,000 ha of sea and $700 \mathrm{~km}$ of coastline (Fig. 1). All the Italian MPAs include three subareas with different levels of protection and accessibility, namely Zone A, Zone B, and Zone C. In Zone A (no-take/no-access zone) the maximum level of protection is enforced (e.g., tourist access is not allowed, while diving is only authorized for research purposes); in Zone B (general protection zone) more activities are allowed (e.g., swimming, authorized professional and recreational fishing); lastly, Zone C (partial protection zone) allows the highest degree of human activities.

Important socio-ecological and cultural features characterize these sites. Noteworthy is the presence of the endemic Mediterranean seagrass Posidonia oceanica and Coralligenous bioconstructions, both representing priority habitats protected under the European Directive 92/43/ EEC (Habitat Directive). Besides their ecological importance, these habitats also represent main tourist attractions enhancing recreational activities such as boating and diving.

\subsection{The environmental accounting model}

In this study, a biophysical and trophodynamic environmental accounting model (Vassallo et al., 2017) was applied to assess the value of natural capital stocks in a set of Italian MPAs.

In particular, all the habitats included within the boundaries of the MPAs were clustered into four main macrohabitats: 1) soft bottom (SB), 2) Posidonia oceanica seagrass beds (PSB), 3) sciaphilic hard bottom (SHB) (coralligenous bioconstruction), and 4) photophilic hard bottom (PHB). The area of the four macro-habitats for the set of investigated MPAs is reported in Table 1. 


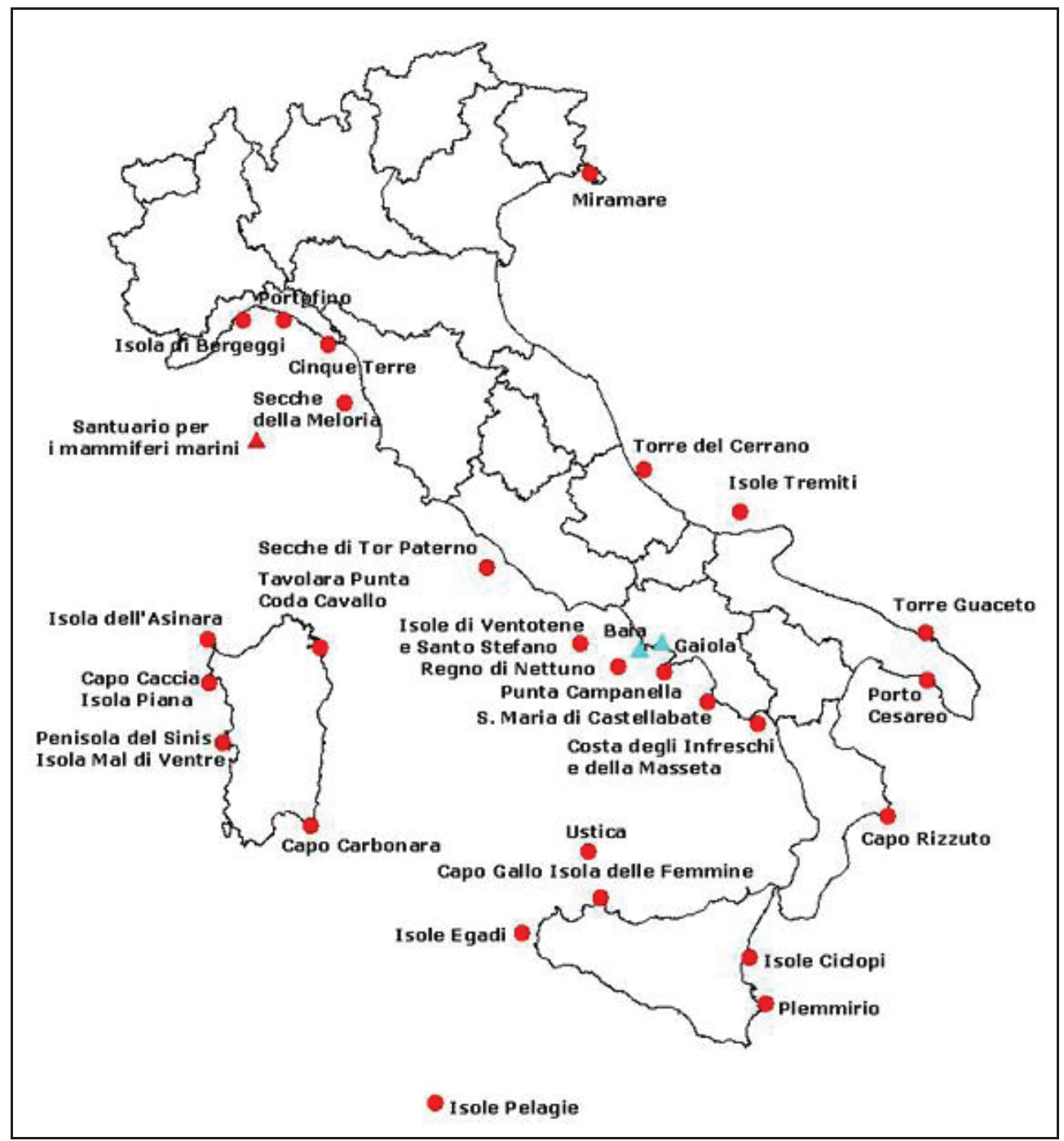

Figure 1. Network of Italian Marine Protected Areas

Table 1. Areas of the investigated Italian MPAs and related macro-habitats.

\begin{tabular}{lccccc}
\hline \multicolumn{1}{c}{ MPA } & SHB (ha) & PHB (ha) & SB (ha) & PSB (ha) & Total (ha) \\
\hline Isole Ventotene e S. Stefano & 100 & 16 & 2297 & 433 & 2850 \\
Punta Campanella & 137 & 19 & 1250 & 143 & 1550 \\
Costa degli Infreschi e della Masseta & 27 & 35 & 2144 & 150 & 2360 \\
S. Maria di Castellabate & 427 & 147 & 3501 & 2857 & 6930 \\
Capo Rizzuto & 808 & 2512 & 11224 & 442 & 15000 \\
Isole Tremiti & 251 & 119 & 938 & 16 & 1320 \\
Isole Egadi & 553 & 5265 & 12434 & 36452 & 53992 \\
Regno di Nettuno & 181 & 177 & 4085 & 1839 & 6282 \\
Isole Pelagie & 2 & 314 & 2904 & 628 & 3849 \\
\hline
\end{tabular}


Ad hoc sampling campaigns were performed to collect data on macrobenthic communities and necto-benthic fishes of each macro-habitat. All identified species were clustered in the following main taxonomic groups: Algae, Annelida, Ascidiacea, Bryozoa, Crustacea, Fishes, Porifera, Echinodermata, Mollusca, and Sipuncula.

The matrixes of the biomass density calculated for the main taxonomic groups were the basis for the environmental accounting model implemented through the following main steps:

1. Identification of the boundaries (spatial and temporal) of the MPAs and their main macro-habitats;

2. Modelling of the MPAs by means of a system diagram drawn according to a standardized energy systems language (Odum, 1996);

3. Biomass inventory of the main taxonomic groups identified in the macro-habitats of the MPAs;

4. Trophodynamic analysis, providing an estimate of the primary productivity used to support the benthic trophic chain within the study areas;

5. Calculation of the main matter and energy flows supporting the generation of natural capital in the different macro-habitats of the MPAs, and conversion of these flows into solar emergy units (Odum, 1996);

6. Calculation of the total emergy value of natural capital stocks for the macro-habitats and the whole MPAs.

In addition, to complement the biophysical assessment with an economic perspective, the emergy values of natural capital were converted into non-market monetary units by using the Emergy-to-Money Ratio (EMR) indicator (www. emergy-nead.com).

\subsection{The Emergy accounting method}

Emergy is an environmental accounting method measuring the cumulative environmental support to a process (Odum, 1988, 1996). The method aims at evaluating the environmental performance of a system on the global scale of the biosphere, taking into account free environmental inputs (e.g., solar radiation, wind, rain, and geothermal flow), human-driven material and energy flows, and the indirect environmental support embodied in human labor and services (Brown and Ulgiati, 2004; Brown et al., 2016a,b; Franzese et al., 2009, 2014). According to this method, inputs are accounted for in terms of their solar emergy, defined as the total amount of solar available energy (exergy) directly or indirectly required to make a given product or support a given flow, and measured in sej (solar equivalent joules). The solar emergy required to generate one unit of product or service is referred to as Unit Emergy Value (UEV, sej $\mathrm{J}^{-1}$, sej $\mathrm{g}^{-1}$ ). Mass, energy, labor, and money inputs to the investigated system are converted into emergy units by using appropriate UEVs, and then summed to calculate the total emergy support.

The UEVs used in this study (Table 2) were updated to the $1.20 \cdot 10^{25}$ sej $\mathrm{yr}^{-1}$ biosphere emergy baseline calculated by Brown et al. (2016a,b).

\section{Results}

Figure 2 shows the systems diagram modelling the investigated MPAs and drawn according to a standardized energy systems language (Odum, 1994; 1996). The systems diagram highlights: a) the main external driving forces supporting the generation of natural capital stocks, b) the

Table 2. UEVs used in this study.

\begin{tabular}{|c|c|c|}
\hline INPUT & UEV (sej unit ${ }^{-1}$ ) & References \\
\hline Solar radiation $(\mathrm{J})$ & 1.00 & By definition \\
\hline Rain (J) & $2.31 \mathrm{E}+04$ & Odum, 1996 \\
\hline Wind $(\mathrm{J})$ & $1.90 \mathrm{E}+03$ & Odum, 1996 \\
\hline Geothermal flow (J) & $1.58 \mathrm{E}+04$ & Brown and Ulgiati, 2010 \\
\hline Tides $(\mathrm{J})$ & $5.68 \mathrm{E}+04$ & Brown and Ulgiati, 2010 \\
\hline Currents $(\mathrm{J})$ & $3.00 \mathrm{E}+04$ & Odum, 1996 \\
\hline Runoff (J) & $5.22 \mathrm{E}+04$ & Odum, 1996 \\
\hline $\mathrm{C}(\mathrm{g})$ & $8.07 \mathrm{E}+07$ & Campbell et al., 2014 \\
\hline $\mathrm{N}(\mathrm{g})$ & $5.84 \mathrm{E}+09$ & Odum, 1996 \\
\hline$P(g)$ & $8.07 \mathrm{E}+07$ & Odum, 1996 \\
\hline
\end{tabular}




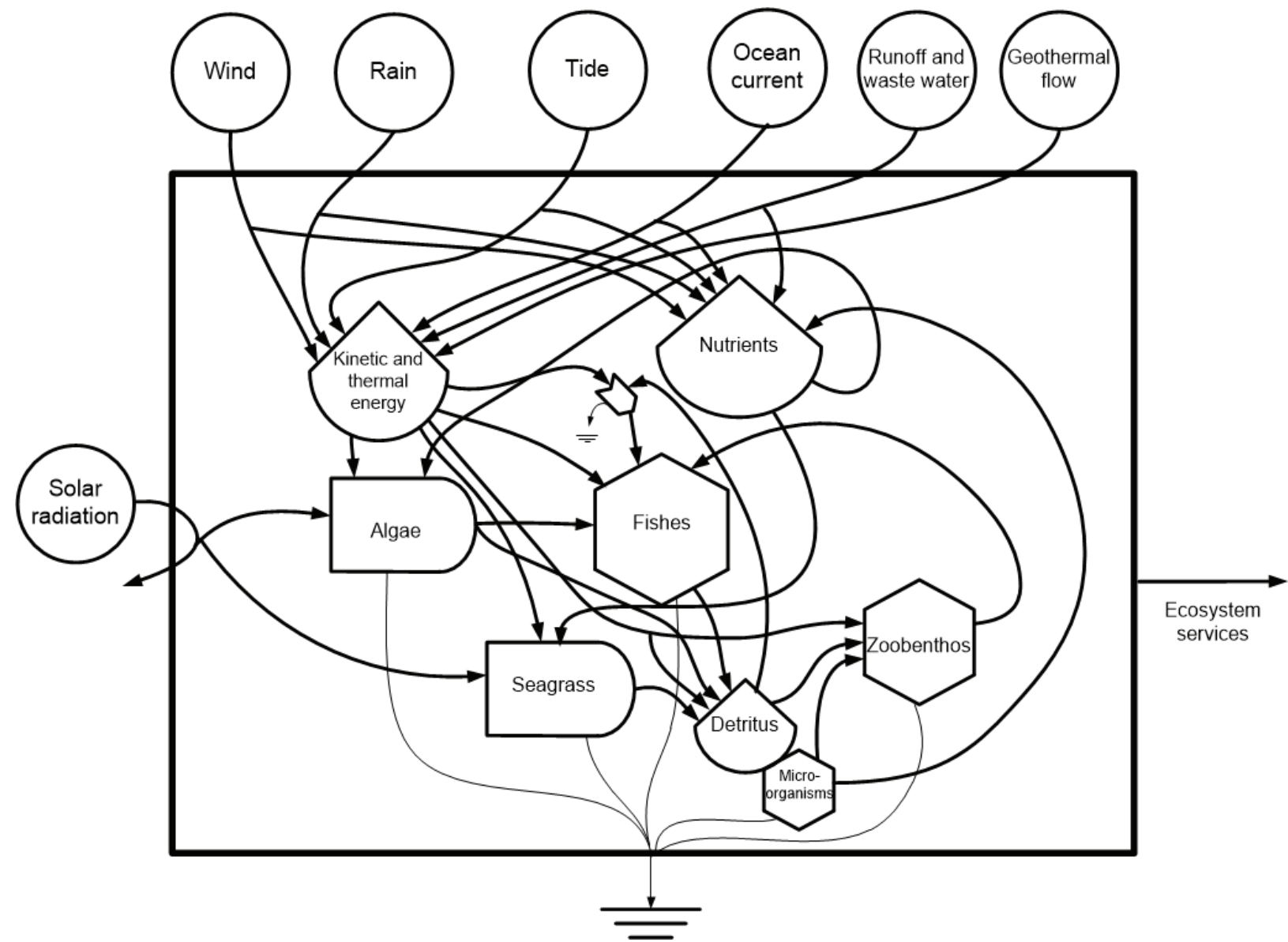

Figure 2. Systems diagram of the investigated MPAs (Franzese et al., 2017).

Table 3. Emergy values of natural capital in the four macro-habitats for selected Italian MPAs.

\begin{tabular}{lccccc}
\hline \multicolumn{1}{c}{ MPA } & SHB (sej) & PHB (sej) & $\begin{array}{c}\text { SB } \\
(\mathbf{s e j})\end{array}$ & $\begin{array}{c}\text { PSB } \\
(\mathbf{s e j})\end{array}$ & Total (sej) \\
\hline Isole Ventotene e S. Stefano & $2.85 \mathrm{E}+18$ & $1.20 \mathrm{E}+17$ & $2.36 \mathrm{E}+18$ & $2.60 \mathrm{E}+18$ & $7.92 \mathrm{E}+18$ \\
Punta Campanella & $6.79 \mathrm{E}+18$ & $4.16 \mathrm{E}+17$ & $2.72 \mathrm{E}+18$ & $1.58 \mathrm{E}+18$ & $1.15 \mathrm{E}+19$ \\
Costa degli Infreschi e della Masseta & $2.51 \mathrm{E}+17$ & $4.44 \mathrm{E}+17$ & $6.27 \mathrm{E}+18$ & $1.83 \mathrm{E}+18$ & $8.79 \mathrm{E}+18$ \\
S. Maria di Castellabate & $1.12 \mathrm{E}+19$ & $2.88 \mathrm{E}+18$ & $8.75 \mathrm{E}+18$ & $2.87 \mathrm{E}+19$ & $5.15 \mathrm{E}+19$ \\
Capo Rizzuto & $1.21 \mathrm{E}+19$ & $5.61 \mathrm{E}+19$ & $1.21 \mathrm{E}+19$ & $4.07 \mathrm{E}+18$ & $8.44 \mathrm{E}+19$ \\
Isole Tremiti & $3.74 \mathrm{E}+18$ & $2.71 \mathrm{E}+18$ & $4.37 \mathrm{E}+18$ & $7.79 \mathrm{E}+16$ & $1.09 \mathrm{E}+19$ \\
Isole Egadi & $1.46 \mathrm{E}+19$ & $1.32 \mathrm{E}+20$ & $1.08 \mathrm{E}+20$ & $8.62 \mathrm{E}+20$ & $1.12 \mathrm{E}+21$ \\
Regno di Nettuno & $4.92 \mathrm{E}+18$ & $4.34 \mathrm{E}+18$ & $1.14 \mathrm{E}+19$ & $2.32 \mathrm{E}+19$ & $4.39 \mathrm{E}+19$ \\
Isole Pelagie & $8.16 \mathrm{E}+16$ & $3.30 \mathrm{E}+18$ & $4.01 \mathrm{E}+18$ & $1.23 \mathrm{E}+19$ & $1.97 \mathrm{E}+19$ \\
\hline
\end{tabular}


producers, consumers, and main storages of the marine ecosystem, and c) the interactions among components.

This symbolic model is useful to implement the quantitative assessment of mass and energy flows, and stocks included within the boundaries of the investigated MPAs.

Table 3 shows the emergy cost supported for the generation of natural capital stocks in each macro-habitat of the MPAs. The emergy costs refer to the evaluation of natural flows and nutrients flows that supported the formation of both autotrophic and heterotrophic natural capital stocks in each of the four investigated macro-habitats. The values ranged from $7.79 \cdot 10^{16}$ sej for the PSB habitat of the "Isole Tremiti" MPA to $8.62 \cdot 10^{20}$ sej for the PSB habitat of the "Isole Egadi" MPA. These values are extensive meas- ures depending on the area of the MPAs and their relative macro-habitats. Instead, the emergy density values (Table 4) account for the emergy flows concentrated per unit area, representing an intensive measure of the emergy support to each macro-habitat.

The emergy density value ranged from $9.15 \cdot 10^{11}$ to $4.94 \cdot 10^{12}$ sej $\mathrm{m}^{-2}$ for the SHB habitat, from $7.43 \cdot 10^{11}$ to $2.50 \cdot 10^{12}$ sej $\mathrm{m}^{-2}$ for the PHB habitat, from $1.03 \cdot 10^{11}$ to $8.67 \cdot 10^{11} \mathrm{sej} \mathrm{m}^{-2}$ for the SB habitat, and from $4.87 \cdot 10^{11}$ to $2.37 \cdot 10^{12}$ sej $\mathrm{m}^{-2}$ for the PSB habitat (Table 4 ).

Table 5 shows the economic value of natural capital calculated for the set of investigated MPAs. The total value of natural capital (i.e., the sum of the values of the four macro-habitats) ranged from about 8 to $1163 \mathrm{M} €$.

Table 4. Emergy density values of natural capital for selected Italian MPAs.

\begin{tabular}{lcccc}
\hline \multicolumn{1}{c}{ MPA } & SHB $\left(\mathbf{s e j} / \mathbf{m}^{2}\right)$ & PHB $\left(\mathbf{s e j} / \mathbf{m}^{2}\right)$ & SB $\left(\mathbf{s e j} / \mathbf{m}^{2}\right)$ & PSB $\left(\mathbf{s e j} / \mathbf{m}^{2}\right)$ \\
\hline Isole Ventotene e S. Stefano & $2.85 \mathrm{E}+12$ & $7.43 \mathrm{E}+11$ & $1.03 \mathrm{E}+11$ & $6.00 \mathrm{E}+11$ \\
Punta Campanella & $4.94 \mathrm{E}+12$ & $2.22 \mathrm{E}+12$ & $2.18 \mathrm{E}+11$ & $1.10 \mathrm{E}+12$ \\
Costa degli Infreschi e della Masseta & $9.15 \mathrm{E}+11$ & $1.27 \mathrm{E}+12$ & $2.92 \mathrm{E}+11$ & $1.22 \mathrm{E}+12$ \\
S. Maria di Castellabate & $2.61 \mathrm{E}+12$ & $1.96 \mathrm{E}+12$ & $2.50 \mathrm{E}+11$ & $1.00 \mathrm{E}+12$ \\
Capo Rizzuto & $1.50 \mathrm{E}+12$ & $2.23 \mathrm{E}+12$ & $1.08 \mathrm{E}+11$ & $9.20 \mathrm{E}+11$ \\
Isole Tremiti & $1.49 \mathrm{E}+12$ & $2.28 \mathrm{E}+12$ & $4.66 \mathrm{E}+11$ & $4.87 \mathrm{E}+11$ \\
Isole Egadi & $2.65 \mathrm{E}+12$ & $2.50 \mathrm{E}+12$ & $8.67 \mathrm{E}+11$ & $2.37 \mathrm{E}+12$ \\
Regno di Nettuno & $2.72 \mathrm{E}+12$ & $2.45 \mathrm{E}+12$ & $2.79 \mathrm{E}+11$ & $1.26 \mathrm{E}+12$ \\
Isole Pelagie & $3.43 \mathrm{E}+12$ & $1.05 \mathrm{E}+12$ & $1.38 \mathrm{E}+11$ & $1.96 \mathrm{E}+12$ \\
\hline
\end{tabular}

Table 5. Economic values of natural capital stocks for selected Italian MPAs.

\begin{tabular}{lccccc}
\hline \multicolumn{1}{c}{ MPA } & $\begin{array}{c}\text { SHB } \\
(€)\end{array}$ & $\begin{array}{c}\text { PHB } \\
(€)\end{array}$ & $\begin{array}{c}\text { SB } \\
(€)\end{array}$ & $\begin{array}{c}\text { PSB } \\
(€)\end{array}$ & $\begin{array}{c}\text { Total } \\
(€)\end{array}$ \\
\hline Isole Ventotene e S. Stefano & $2.97 \mathrm{E}+06$ & $1.25 \mathrm{E}+05$ & $2.46 \mathrm{E}+06$ & $2.70 \mathrm{E}+06$ & $8.25 \mathrm{E}+06$ \\
Punta Campanella & $7.08 \mathrm{E}+06$ & $4.34 \mathrm{E}+05$ & $2.84 \mathrm{E}+06$ & $1.64 \mathrm{E}+06$ & $1.20 \mathrm{E}+07$ \\
Costa degli Infreschi e della Masseta & $2.61 \mathrm{E}+05$ & $4.62 \mathrm{E}+05$ & $6.53 \mathrm{E}+06$ & $1.91 \mathrm{E}+06$ & $9.16 \mathrm{E}+06$ \\
S. Maria di Castellabate & $1.16 \mathrm{E}+07$ & $3.00 \mathrm{E}+06$ & $9.12 \mathrm{E}+06$ & $2.99 \mathrm{E}+07$ & $5.36 \mathrm{E}+07$ \\
Capo Rizzuto & $1.27 \mathrm{E}+07$ & $5.84 \mathrm{E}+07$ & $1.26 \mathrm{E}+07$ & $4.24 \mathrm{E}+06$ & $8.79 \mathrm{E}+07$ \\
Isole Tremiti & $3.90 \mathrm{E}+06$ & $2.82 \mathrm{E}+06$ & $4.55 \mathrm{E}+06$ & $8.11 \mathrm{E}+04$ & $1.14 \mathrm{E}+07$ \\
Isole Egadi & $1.53 \mathrm{E}+07$ & $1.37 \mathrm{E}+08$ & $1.12 \mathrm{E}+08$ & $8.98 \mathrm{E}+08$ & $1.16 \mathrm{E}+09$ \\
Regno di Nettuno & $5.13 \mathrm{E}+06$ & $4.52 \mathrm{E}+06$ & $1.19 \mathrm{E}+07$ & $2.42 \mathrm{E}+07$ & $4.57 \mathrm{E}+07$ \\
Isole Pelagie & $8.50 \mathrm{E}+04$ & $3.44 \mathrm{E}+06$ & $4.18 \mathrm{E}+06$ & $1.28 \mathrm{E}+07$ & $2.05 \mathrm{E}+07$ \\
\hline
\end{tabular}




\section{Discussion}

Accounting for the biophysical and economic value of natural capital stocks is the basis for the sustainable management of natural resources, especially in the case of MPAs meant to protect biological diversity while ensuring sustainable human activities.

In this study, the value of natural capital stocks in selected Italian MPAs was assessed through the lens of the biophysical perspective of the emergy accounting method.

The emergy density value of the SHB habitat (coralligenous bioconstructions) resulted higher than all other habitats for most of the investigated MPAs. The high emergy cost calculated for the SHB habitat is due to the high convergence of natural input flows for its generation, confirming the importance of coralligenous habitats in coastal marine ecosystems (Ferrigno et al., 2017; Appolloni et al., 2020a).

When considering extensive indicators, the contribution of the SHB habitat to the total value of natural capital was higher than other habitats in the case of "Punta Campanella" and "Isole di Ventotene e Santo Stefano" MPAs (Figure 3). Instead, the PSB habitat showed higher value compared to other habitats for four investigated MPAs (Figure 3). In particular, the contribution of the PSB habitat to the total value of natural capital was very high in the case of the "Isole Pelagie" (62\%) and "Isole Egadi" (77\%) MPAs.

These outcomes highlight the importance of protecting $P$. oceanica seagrass beds representing one of the most important habitat formers in the Mediterranean Sea whose primary production generates significant biomass stocks associated with high biodiversity (Appolloni et al., 2020b; de Virgilio et al., 2020).

Only in the case of "Capo Rizzuto" MPA, the PHB habitat showed the highest contribution to the total natural capital value (Figure 3). In fact, although this habitat covers about $17 \%$ of the total MPA area, its emergy density value was higher than all the other habitats (Table 4). This peculiar feature highlights that the SHB habitat deserves particular attention in the conservation planning of the MPA of "Capo Rizzuto".

In the case of "Costa degli Infreschi e della Masseta" and "Isole Tremiti" MPAs the SB habitat showed the highest contribution to the total natural capital value. This was mainly due to the area covered by this habitat accounting for about $51 \%$ and $71 \%$ of the total MPAs area, respectively.

In addition, the conversion of the emergy values into non-market monetary units provided a complementary perspective to the biophysical assessment. Nonetheless, it is noteworthy that results expressed in monetary equivalent still represent the environmental cost for natural capital

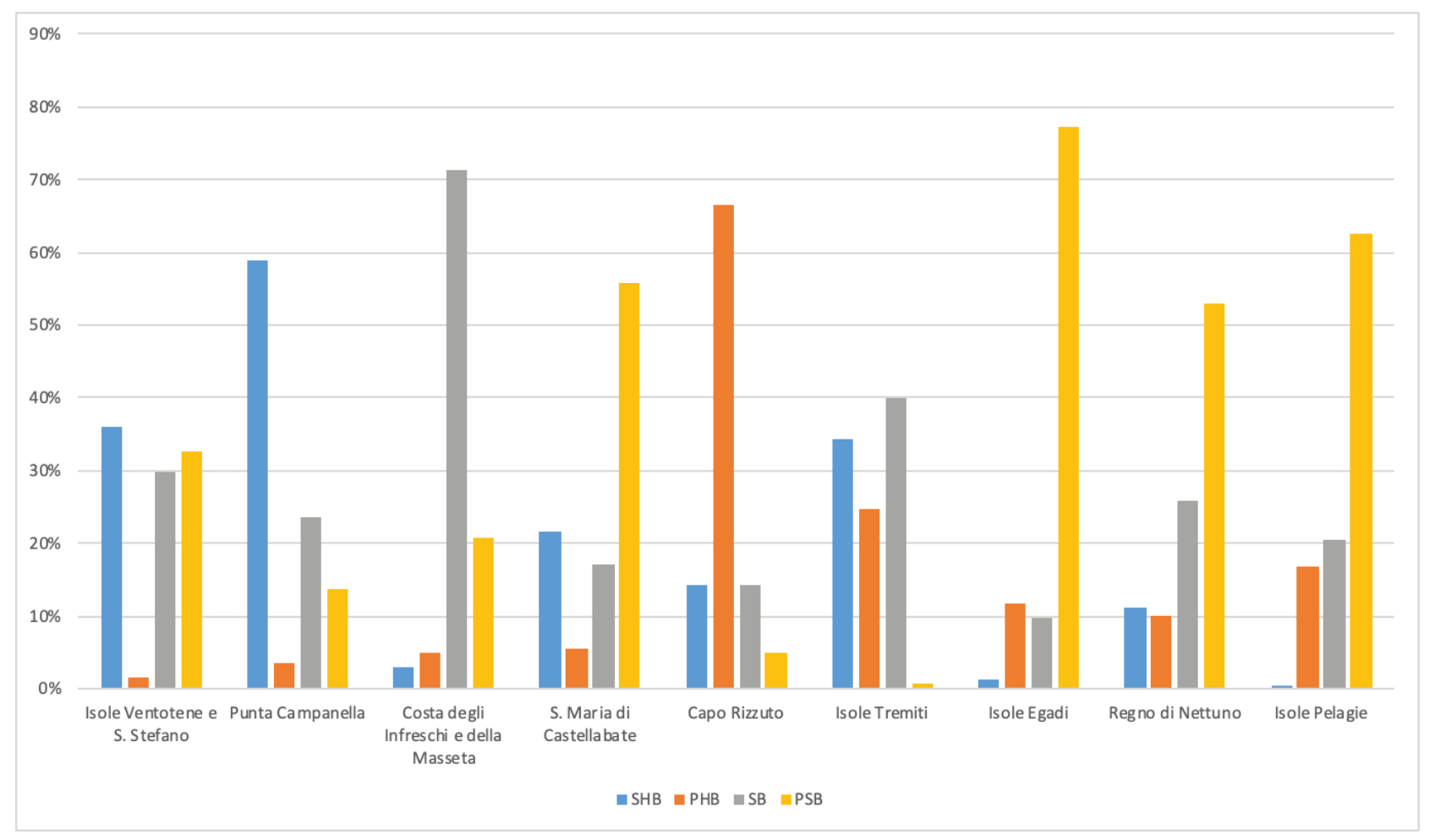

Figure 3. Contribution of the four macro-habitats to the total value of natural capital in the investigated Italian MPAs. 
stocks generation but, at the same time, allow for an easier understanding of the outcomes of the study in socio-economic contexts.

The assessment of natural capital value in the Italian MPAs was based on the implementation of a standardized protocol developed in the framework of the Italian national project. The standardization of the sampling techniques and the development of an ad hoc environmental accounting model allowed the comparison of the results obtained for the different MPAs.

Nonetheless, the complexity and openness of marine ecosystems along with the limited data and resources availability forced to adopt several simplifications in the development of the environmental accounting model. For instance, the main focus was on benthic macro-habitats while the pelagic domain was not investigated. Moreover, while multiple samplings were performed to estimate the biomass data, the clustering of the benthic habitats into macro-habitats may simplify the habitat heterogeneity within MPAs. Nevertheless, in future studies the accounting model could be modified and adapted to assess the natural capital value of specific habitats that are peculiar in some Italian MPAs, such as vermetid reefs and other bioconstructions (Donnarumma et al., 2018; Ingrosso et al., 2018).

\section{Conclusions}

In this study, a biophysical and trophodynamic model based on the Emergy accounting method was used to assess the value of natural capital stocks in a set of Italian MPAs.

The value of natural capital was calculated for each macro-habitat and for the whole MPAs in both biophysical and economic terms. While the biophysical value reflects the ecological dynamics in the MPAs, the economic value is useful to better communicate the outcomes of the biophysical assessment in socio-economic contexts.

Therefore, assessing the biophysical and economic value of natural capital can support local managers and policy makers in charge for achieving nature conservation targets while ensuring the sustainable exploitation of natural resources.

The outcomes of this study may be updated in the future on the base of new and comprehensive biomass dataset and bionomic maps.

Finally, according to the goals of the national project, the accounting of natural capital value will be integrated with an ecological-economic assessment of the bundle of ecosystem services underpinned by MPAs.

\section{References}

Appolloni L., Ferrigno F., Russo G.F., Sandulli R., 2020a. $\beta$-Diversity of morphological groups as indicator of coralligenous community quality status. Ecological Indicators 109: 105840.

Appolloni L., Buonocore E., Russo G.F., Franzese, P.P., 2020b. The use of remote sensing for monitoring posidonia oceanica and marine protected areas: A systemic review. Ecological Questions 31(2): 7-17.

Armoškaitè A., Puriņa I., Aigars J., Strāḳe S., Pakalniete K., Frederiksen P., Schrøder L., H.S. Hansen, 2020. Establishing the links between marine ecosystem components, functions and services: An ecosystem service assessment tool. Ocean \& Coastal Management 193: 105229.

Barbier E., 2014. Economics: Account for depreciation of natural capital. Nature 515: 32-33.

Berrios F., Campbell D.E., Ortiz M., 2017. Emergy evaluation of benthic ecosystems influenced by upwelling in northern Chile: contributions of the ecosystems to the regional economy. Ecological Modelling 359: 146164.

Brown M.T., Ulgiati S., 2004. Emergy Analysis and Environmental Accounting. In: Encyclopedia of Energy, C. Cleveland Editor, Academic Press, Elsevier, Oxford, UK, pp. 329-354.

Brown M.T., Ulgiati S., 2010. Updated evaluation of exergy and emergy driving the geobiosphere: A review and refinement of the emergy baseline. Ecological Modelling 221: 2501-2508.

Brown M.T., Campbell D.E., De Vilbiss C., Ulgiati S., 2016a. The geobiosphere emergy baseline: A synthesis. Ecological Modelling 339: 92-95.

Brown M.T., Campbell D.E., Ulgiati S., Franzese P.P., 2016b. The geobiosphere emergy baseline: A synthesis. Ecological Modelling 339: 89-91.

Buonocore E., Picone F., Russo G.F., Franzese P.P., 2018. The Scientific Research On Natural Capital: A Bibliometric Network Analysis. Journal of Environmental Accounting and Management 6(4): 374-384.

Buonocore, E., Picone, F., Donnarumma, L., Russo, G. F., Franzese P. P., 2019. Modeling matter and energy flows in marine ecosystems using emergy and eco-exergy methods to account for natural capital value. Ecological Modelling 392: 137-146.

Buonocore E., Donnarumma L., Appolloni L., Russo G.F., Franzese P.P., 2020. Marine natural capital and ecosystem services: An environmental accounting model. Ecological Modelling 424, 109029.

Campbell D.E., Lu H., Lin B.L., 2014. Emergy evaluations of the global biogeochemical cycles of six biologically 
active elements and two compounds. Ecological Modelling 271: 32-51.

Cattaneo-Vietti R., Bo M., Cannas R., Cau A., Follesa C., Meliadò E., Russo G.F., Sandulli R., Santangelo G., Bavestrello G. (2016). An overexploited Italian treasure: past and present distribution and exploitation of the precious red coral Corallium rubrum (L., 1758) (Cnidaria: Anthozoa). Italian Journal of Zoology, vol. 83, no. 4, pp. 443-455.

Cavanagh R.D., Broszeit S., Pilling G.M., Grant S.M., Murphy E.J., Austen M.C., 2016 Valuing biodiversity and ecosystem services: a useful way to manage and conserve marine resources? Proc. R. Soc. B 283: 20161635.

Chan K.M., Balvanera P., Benessaiah K., Chapman M., Díaz S., Gomez-Baggethun E., Gould, R., Hannahs N., Jax K., Klain, S., 2016. Opinion: why protect nature? Rethinking values and the environment. Proc. Natl. Acad. Sci. U.S.A. 113: 1462-1465.

Christie M., Remoundou K., Siwicka E., Wainwright W., 2015. Valuing marine and coastal ecosystem service benefits: Case study of St Vincent and the Grenadines' proposed marine protected areas. Ecosystem Services 11: 115-127.

de Virgilio M., Cifarelli S., de Gennaro P., Garofoli G., Degryse B., 2020. A first attempt of citizen science in the genetic monitoring of a Posidonia oceanica meadow in the Italian Southern Adriatic Sea. Journal for Nature Conservation 56: 125826.

Donnarumma L., Sandulli R., Appolloni L., Di Stefano F., Russo G. F., 2018. Morpho-structural and ecological features of a shallow vermetid bioconstruction in the tyrrhenian sea (mediterranean sea, italy). Journal of Sea Research 131, 61-68.

Ferrigno F., Russo G.F., Sandulli R., 2017. Coralligenous bioconstructions quality index (CBQI): A synthetic indicator to assess the status of different types of coralligenous habitats. Ecological Indicators 82: 271-279.

Franzese P.P., Russo G.F., Ulgiati S., 2008. Modelling the interplay of environment, economy and resources in Marine Protected Areas. A case study in Southern Italy. Ecological Questions 10: 91-97.

Franzese P.P., Rydberg T., Russo G.F., Ulgiati S., 2009 Sustainable biomass production: A comparison between Gross Energy Requirement and Emergy Synthesis methods. Ecological Indicators 9 (5): 959-970.

Franzese P.P., Brown M.T., Ulgiati S., 2014. Environmental accounting: Emergy, systems ecology, and ecological modelling. Ecological Modelling 271: 1-3.

Franzese P.P., Buonocore E., Paoli C., Massa F., Stefano D., Fanciulli G., et al., 2015. Environmental Accounting in Marine Protected Areas: the EAMPA Project. Journal of Environmental Accounting and Management 3(4): 324-332.
Franzese P.P., Buonocore E., Donnarumma L., Russo G.F., 2017. Natural capital accounting in marine protected areas: The case of the Islands of Ventotene and S. Stefano (Central Italy). Ecological Modelling 360: 290-299.

Halpern B.S., 2003. Impact of marine reserves: Do reserves work and does reserve size matter? Ecological Applications 13: 117-137.

Halpern B.S, Walbridge S., Selkoe K.A., Kappel C.V., Micheli F., D’Agrosa C., et al., 2008. A Global Map of Human Impact on Marine Ecosystems. Science 319: 948-952.

Halpern B.S., Frazier M., Afflerbach J. et al., 2019. Recent pace of change in human impact on the world's ocean. Sci Rep 9: 11609.

Hattam C., Atkins J. P., Beaumont N., Börger T., Böhnkehenrichs A., Burdon D., et al., 2015. Marine ecosystem services: Linking indicators to their classification. Ecological Indicators 49: 61-75.

Häyhä T., Franzese P.P., 2014. Ecosystem services assessment: A review under an ecological-economic and systems perspective. Ecological Modelling 289: 124-132.

Ingrosso G., Abbiati M., Badalamenti F., Bavestrello G., Belmonte G., Cannas R. et al., 2018. Mediterranean bioconstructions along the italian coast. Advances in Marine Biology 79: 61-136.

Odum H.T., 1988. Self organization, transformity and information. Science 242: 1132-1139.

Odum H.T., 1994. Ecological and General Systems. An Introduction to Systems Ecology (Revised Edition). University Press of Colorado, $644 \mathrm{pp}$.

Odum H.T., 1996. Environmental Accounting: Emergy and Environmental Decision Making. John Wiley and Sons. New York, 369 pp.

OECD, 2017. Marine Protected Areas: Economics, Management and Effective Policy Mixes. OECD Publishing, Paris.

Paoli C., Povero P., Burgos E., Dapueto G., Fanciulli G., Massa F., et al., 2018. Natural capital and environmental flows assessment in marine protected areas: The case study of Liguria region (NW Mediterranean Sea). Ecological Modelling 368: 121-135.

Pauna V.H., Picone F., Le Guyader G., Buonocore E., Franzese P.P., 2018. The scientific research on ecosystem services: A bibliometric analysis. Ecological Questions 29 (3): 53-62.

Pauna V.H., Buonocore E., Renzi M., Russo G.F., Franzese P.P., 2019. The issue of microplastics in marine ecosystems: A bibliometric network analysis. Marine Pollution Bulletin 149: 110612.

Picone F., Buonocore E., D’Agostaro R., Donati S., Chemello R., Franzese P.P., 2017. Integrating natural capital assessment and marine spatial planning: A case study in the Mediterranean sea. Ecological Modelling 361: 1-13. 
Rasheed A.R., 2020. Marine protected areas and human well-being - A systematic review and Recommendations. Ecosystem Services 41, 101048.

Schumann P.W., Mahon R., 2015. The valuation of marine ecosystem goods and services in the Caribbean: A literature review and framework for future valuation efforts. Ecosystem Services 11: 56-66.

TEEB, 2010. The Economics of Ecosystems and Biodiversity for Local and Regional Policy Makers.

UNEP, 2006. Marine and coastal ecosystems and human well-being: A synthesis report based on the findings of the Millennium Ecosystem Assessment. UNEP. 76pp.

UNEP-WCMC and IUCN, 2019. Marine Protected Planet [On-line], [December, 2019], Cambridge, UK: UNEPWCMC and IUCN Available at: www.protectedplanet. net. van Dijk J., Dick J., Harrison P., Jax K., Saarikoski H., Furman E., 2018. Editorial: Operationalisation of natural capital and ecosystem services. Ecosystem Services 29, Part C: 411-414.

Vassallo P., Paoli C., Buonocore E., Franzese P.P., Russo G.F., Povero P., 2017. Assessing the value of natural capital in marine protected areas: A biophysical and trophodynamic environmental accounting model. Ecological Modelling 355: 12-17.

Vihervaara, P., Franzese, P. P., Buonocore, E., 2019. Information, energy, and eco-exergy as indicators of ecosystem complexity. Ecological Modelling 395: 23-27.

Yu H., Wang Y., Li X., Wang C., Sun M., Du A., 2019. Measuring ecological capital: State of the art, trends, and challenges. Journal of Cleaner Production 219: 833-845. 